\title{
Party Change in Chile in Comparative Perspective*
}

\author{
ALAN ANGELL \\ St Antony's College, University of OXford, United Kingdom
}

\begin{abstract}
Resumen
Este artículo estudia los cambios generales en los sistemas de partidos en las democracias modernas y argumenta que muchas de las tendencias que se observan internacionalmente -como el aumento en la desconfianza en los partidos, o desalineaciones electorales cada vez mayores- también se observan en Chile. De esta forma, cualquier análisis de cambios en el sistema de partidos de Chile tiene que considerar lo que está sucediendo en otros países con sistemas de partidos bien establecidos. El artículo postula que la comparación del sistema de partidos chileno con el pasado reciente tiende a estar limitado al período excepcional 1964-1973 y que un análisis más extendido implicaría muchas más continuidades de las esperadas. También se cuestiona las nuevas discusiones sobre si existe o no una nueva fisura partidaria, basada en la oposición entre el apoyo y rechazo al sistema autoritario, o el apoyo a la democracia.
\end{abstract}

\begin{abstract}
This article looks at the changes in party systems generally in modern democracies, and argues that many trends observed internationally - growing mistrust of parties, growing electoral de-alignment - are also observed in Chile. Hence any analysis of party change in Chile has to take into account what is happening in other countries with well-established party systems. The article argues that the comparison with the past tends to be limited to the exceptional 1964-1973 period and that a more extended analysis points to many continuities in the Chilean party system. Competing arguments over whether there is new party cleavage in Chile based on the opposition between support for authoritarianism or support for democracy are also examined*.
\end{abstract}

\section{PALABRAS CLAVE • Chile • Partidos Políticos • Elecciones • Coalición • Democratización • Financiamiento Político}

Analysis of the contemporary Chilean party system tends to assume (as does analysis of parties in many other countries) that there is a long-term process of party decline. Discussion concentrates on changes in the electoral behaviour of parties as if this were the only variable to analyse; and the comparison with the past tends to be limited to party behaviour in the 1964-1973 period - arguably an exceptional period in the story of party development in Chile. What is happening to parties in Chile needs to be related to the changes taking place world-wide in party systems.

Recent writing on party systems (Dalton and Wattenberg, 2002) has emphasised the need to analyse parties in terms of three related but distinct functions. Parties clearly play the major role in organising elections, in providing choices for the electorate, in stimulating and mobilising electoral

* The second part of this article draws on material from my chapter in Chile to be published in Manuel Alcántara and Roberto Espíndola, (eds) forthcoming 2004, Political Parties in Latin America (London: Routledge Press) I would like to thank Fernando Sánchez for help with the data in this article. 
participation. It is relatively easy to discuss the role of parties in this dimension by electoral analysis. But parties also play other roles and provide other services in democratic systems. Parties are organisations, and need to be analysed as such. ${ }^{1}$ Parties train the political elite, they select candidates for office, they represent and aggregate interests, and they organise many aspects of political life. Analysis of parties as organisations is less well developed and requires a different kind of data from electoral analysis.

Finally parties also have a role as agents of government. Parties play a vital role in creating stable government and in providing opposition to it, and are crucial as mechanisms for providing effective but also accountable government. Of course parties can fail disastrously on these last two dimensions - as organisations and as agents for providing government - and if they do so, then the consequences for political stability and democracy can be severe (as the cases of Argentina, Peru and Venezuela show).

What is interesting is how far there is a world-wide change in the functions of parties, observable in a large number of countries. Recent research (Dalton and Wattenberg, 2002; Pharr and Putnam, 2000; Gunther et. al., 2002) has demonstrated a general international trend of increasing dissatisfaction with parties and increasing electoral de-alignment. This process has given rise to the much-commented 'decline of the political parties'. But analysed as organisations the story is rather one of adaptation and change rather than decline (Mair, 1997). Parties are responding to a number of social and economic changes by changing the way they are organised and the functions they perform. What may be appropriate to party behaviour at a time of sharp class conflict grounded in competing ideologies is not appropriate to the changed conditions of the contemporary world. And, finally, it is difficult to discern any noticeable trend in the role of parties as providers of government - whether this is done badly or well does not fit into any overall trend or pattern.

\section{DOES CHILE SHARE THESE COMPARATIVE TRENDS?}

The answer broadly is that the trends observed internationally are also observable in Chile. Surveys of public opinion frequently ask the respondents if they have any degree of trust in political parties. It is also frequently asserted that trust in parties is low in Chile. In fact, in comparative terms, Chile occupies a middle position between the low of $4 \%$ level of trust in Argentina to the (not very) high of $36 \%$ in Holland and Denmark. Figure 1 indicates that the level of trust in parties in Chile is not very different from that in France or Britain. 
FIGURE 1: Trust in Political Parties in EU, Latin American, and Post-Communist Countries, 2001/2

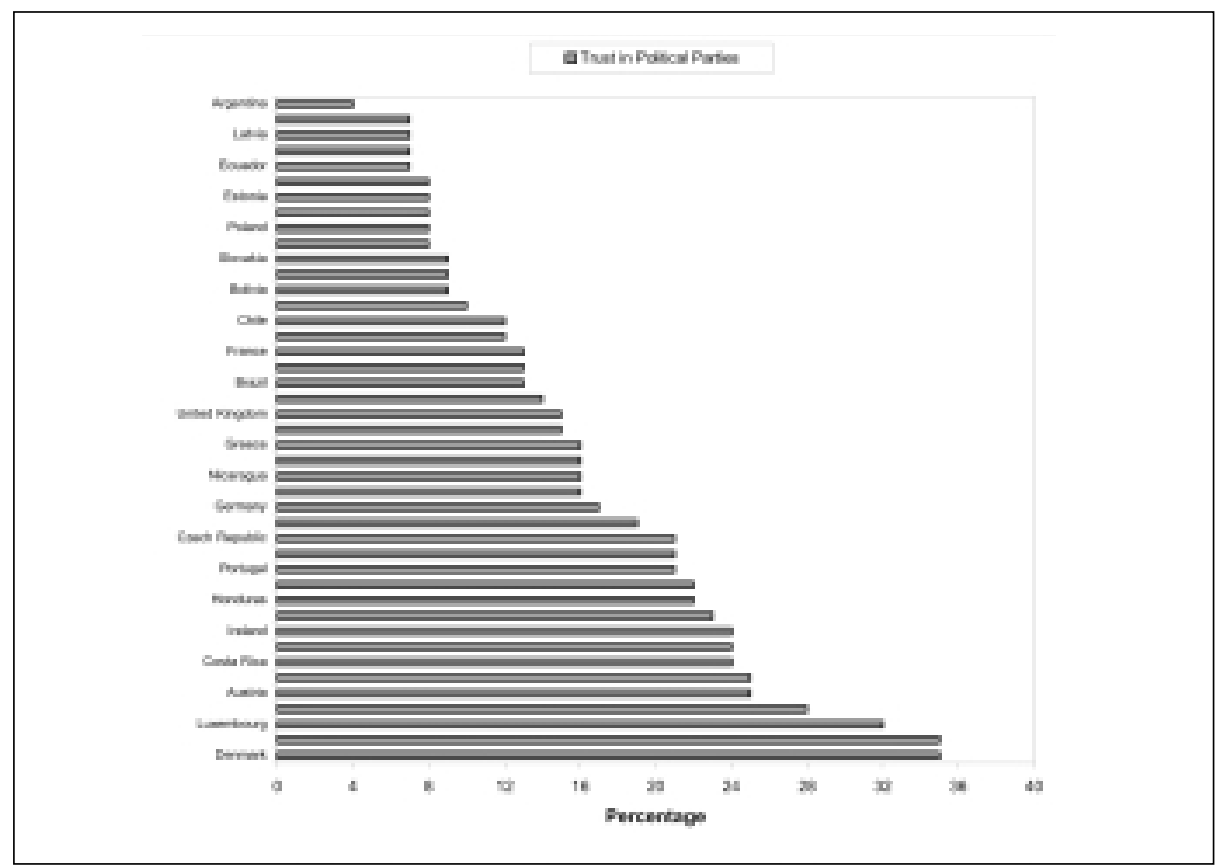

Sources: Latinobarómetro 2002; Eurobarometer Spring 2002; Data for Latin American countries and for UE members correspond to 2002, and information for post-Communist nations to 2001.

It is also true that confidence or trust in political parties in Chile has been declining in recent years. A question in Latinobarométro about the level of confidence in parties in Chile showed a decline from 35\% in 1997 expressing confidence to only 12\% expressing confidence in 2002 . One could seek explanations for this in terms of the effect of the sharp decline in the level of economic growth, the rise in unemployment, the increase in party hostility as the Right emerged as a credible presidential threat, the perception of rising levels of crime and so on. Yet the problem with this explanation is that a similar decline is observed in all countries of Latin America - though it is sharper in Chile than most, as Table 1 shows. 
TABLE 1: Change in Confidence in Political Parties in Latin America, 1997-2002

\begin{tabular}{lccc}
\hline Country & $\begin{array}{c}\text { \% of confidence } \\
\text { in parties 1997 }\end{array}$ & $\begin{array}{c}\text { \% of confidence } \\
\text { in parties 2002 }\end{array}$ & \% of Change \\
\hline Costa Rica & 26 & 24 & -7.7 \\
Venezuela & 21 & 19 & -9.5 \\
Brazil & 18 & 13 & -27.8 \\
Peru & 20 & 13 & -35.0 \\
Uruguay & 45 & 28 & -37.8 \\
Panama & 28 & 16 & -42.9 \\
Honduras & 40 & 22 & -45.0 \\
Nicaragua & 30 & 16 & -46.7 \\
Colombia & 21 & 10 & -52.4 \\
Bolivia & 20 & 9 & -55.0 \\
Ecuador & 16 & 7 & -56.3 \\
Mexico & 31 & 12 & -61.3 \\
El Salvador & 45 & 16 & -64.4 \\
Chile & 35 & 12 & -65.7 \\
Guatemala & 24 & 8 & -66.7 \\
Paraguay & 27 & 7 & -74.1 \\
Argentina & 29 & 4 & -86.2 \\
\hline Latin America (average) & 19 & 14 & -26.3 \\
\hline
\end{tabular}

Sources: Latinobarómetro 1996-1997; Latinobarómetro 2002.

Another measure of the importance of political parties in the political culture of a country is the level of partisan identification - the extent to which the electorate identify with one or other political party. The problem with this data is that it is relatively limited in time, not conducted using the same survey methods, and not always with the same question. However Table 2 shows a general tendency towards a decline in party identification for a number of countries in Latin America - including those regarded as having the most institutionalised party systems. 
TABLE 2: Partisan Identification in Latin American Countries

\begin{tabular}{|c|c|c|}
\hline Country & Years & \% Identifying with a Party (PPID) \\
\hline \multirow[t]{2}{*}{ Argentina } & 1989 & 44.4 \\
\hline & 1995 & 24.6 \\
\hline \multirow[t]{4}{*}{ Chile } & 1967 & 88.5 \\
\hline & 1988 & 80.0 \\
\hline & 1991-1994 (avg.) & 75.0 \\
\hline & 1996 & 50.0 \\
\hline \multirow[t]{2}{*}{ Colombia } & 1970's & 70.0 \\
\hline & 1980's & 60.0 \\
\hline \multirow[t]{6}{*}{ Costa Rica } & 1978-1982 (avg.) & 71.5 \\
\hline & 1982-1986 (avg.) & 74.8 \\
\hline & 1986-1990 (avg.) & 82.0 \\
\hline & 1990-1994 (avg.) & 79.6 \\
\hline & 1994-1998 (avg.) & 70.1 \\
\hline & 1998-2002 (avg.) & 66.1 \\
\hline \multirow[t]{2}{*}{ Mexico } & 1987 & 62.0 \\
\hline & 1990 & 49.0 \\
\hline \multirow[t]{4}{*}{ Uruguay } & 1966 & 79.0 \\
\hline & 1971 & 79.0 \\
\hline & 1994 & 74.0 \\
\hline & 1999 & 84.0 \\
\hline \multirow[t]{4}{*}{ Venezuela } & 1973 & 45.9 \\
\hline & 1983 & 35.3 \\
\hline & 1993 & 27.8 \\
\hline & 1998 & 14.0 \\
\hline
\end{tabular}

Source: Sánchez: 2003: 230-232.

But this trend in not limited to Latin America. Studies of partisan identification in the developed countries show a similar trend. For example, in Sweden it fell from 90\% average over 1968-1985 to $64 \%$ in 1988 . In Britain those expressing strong identification fell from $44 \%$ in the period 1964 1966 to a mere $15.4 \%$ in the $1992-1997$ period.

Similar trends can be observed if we examine other measures of the centrality of parties in the political process. It is true that electoral participation in Chile (to be discussed later) has declined, but so it has throughout the world and the Chilean level of electoral participation (given the curious system of voluntary registration but compulsory voting) is still relatively high. A comparison of the 
first two elections of the 1950s with the two most recent elections shows a decline in electoral turnout in Switzerland from $60.8 \%$ to $36.9 \%$; in the USA from $61.7 \%$ to $52.2 \%$; in Britain from $81.5 \%$ to $72.0 \%$. Only two countries out of nineteen modern democracies showed an increase in electoral turnout (Dalton and Wattenberg: 2002:71). It is often commented that the failure to register to vote is increasing in Chile. But it is also true that in many other countries potential voters are failing to register to vote - in France of the potential electorate, the proportion failing to register has increased from 8\% in 1952 to over 14\% in the 1990s, and in Britain the number of nonregistered potential voters has doubled in the last thirty years (Dalton and Wattenberg: 2002:70). On the index that measures electoral volatility, Chile is very low indeed compared with many countries in Latin America such as Peru, Venezuela or Argentina which witness very major shifts in voting for parties in different elections. ${ }^{2}$

\section{EXPLAINING CHANGES IN PARTY IDENTIFICATION AND ELECTORAL DE-ALIGNMENT}

A considerable number of explanations have been offered to explain the recent changes that have been observed in the level of support expressed for parties in modern democracies. Central to these explanations is a clear decline in the importance of ideological clash as the end of communism as a system, and of marxism as an ideology reduced the political alternatives available to the electorate. There is little doubt that most parties in modern democracies now occupy a centre ground in politics, expressing support for the free market and the importance of consumer choice in a wide sphere of activities.

There are also sociological changes that help to explain the lessening of the sharp social cleavages that characterised party politics for the most of the twentieth century. An increasingly educated electorate is more able to evaluate the performance of parties and to vote according to that evaluation rather than vote out of loyalty forged by family and community and workplace attachment. The classical organisations of the working class - militant trade unions - are much diminished in power as occupational changes have reduced the traditional bastions of the organised working class - mines and large industrial establishments - in favour of more volatile employment in the service sector. An increasingly mobile work force has lost some of the traditional community attachment of previous decades.

Parties themselves have changed in a way that discourages political mobilisation. Politics is now a much more professional occupation in which the traditional importance of the rank-and-file is much diminished. The focus- group is more important to the modern political party than the traditional mass rally of the past. Militant and participatory involvement is now much more likely to be found in social movements such as the women's movement, the environmental movement or the indigenous movement. If it is noticeable that there is little enthusiasm amongst the young for conventional party politics, there is by contrast much greater enthusiasm for the radical single-issue social movements.

Politics has become much more expensive as the increased use of the media, and the increasing need for candidate recognition rather than party identification, has pushed up campaign costs way

For a discussion of increasing electoral volatility in modern democracies see Dalton and Wattenberg: 2002, 40-41. 
beyond the capacity of member's contributions to finance. Parties seek funds from business, from foundations, from large organisations rather than the members. If the media influence politics more than in the past - especially TV - then the parties will spend more time trying to ensure favourable media coverage than they will rallying the party faithful to campaign for the party. Money and the media are seen to be the keys to successful electioneering not the size of the public rallies of support for the parties.

What is not seen as central to the process of de-alignment is any supposed secular decline in the performance of parties as agents of government. No doubt some governments are worse than others are but there is no linear trend in this regard. Nor does it seem that a successful government necessarily reduces or reverses the process of partisan de-alignment and growing mistrust of parties. On most measures party government in Chile since 1990 has been a success - a long period of sustained economic growth, political stability and increasing average earnings. A World Bank Governance Project created a series of indicators to measure the quality of governance involving such criteria as political stability, government effectiveness, regulatory quality, rule of law, control of corruption and voice and accountability. Chile was easily the best-rated country in Latin America with a score of 6.32 - next were Costa Rica and Uruguay with scores of 5.55 and 5.03. By contrast Argentina scored only 1.41, Brazil 0.58 and Colombia -3.29 . (World Bank, 2002). Yet this was not sufficient to make Chile different from the Latin American trend of decline in the trust expressed by the electorate in political parties.

\section{PARTY CHANGE IN CHILE: AN HISTORICAL NOTE}

Commentators often assume, explicitly or implicitly, that the decline of parties since 1990 has to be measured against an earlier period of mass, participatory parties, when ideological and programmatic differences were clear and hotly debated not just at the elite level but also at the level of the ordinary member. In other words they were truly parties of masses and not parties of elites more concerned to suppress than to express popular sentiment. The assumption often made is that ordinary members' opinions were taken into account in framing party policy.

But is this picture of the past accurate? It is difficult to be authoritative in the absence of detailed studies of party organisation and behaviour in contrast to the many studies of party ideology. Undoubtedly the parties did have deep social roots in some areas, there was fierce electoral competition and there were pronounced ideological differences. At least there was in the period 1964 to 1973. But was this period typical or not? Probably not - and that period was exceptional not just in Chile but in many parts of Latin America and indeed in the world (remember the events of 1968 for example). If we look to earlier periods of Chilean party history we have a very different picture. Had there been reliable polls in, for example, 1946 to 58, it is not at all obvious that the level of public trust or confidence in the parties would have been very different from the levels of today. Certainly there was massive rejection of the parties in the election of 1952, even if the desertion was of a temporary nature. There was also much greater electoral volatility as parties like the Partido Agrario Laborista rose and declined, or the Christian Democrats suddenly moved from small minority to almost majority status. Maybe the Popular Front period has some similarities to the 1964-73 period, but then the 1920 s look more like the 1946 to 58 period. In other words it 
is very misleading to contrast parties today with a model of parties based on an unusual period in Chilean party development. Change in the relative support for different parties or even temporary crises of public confidence in parties should not be confused with a fundamental shift in the basis of the party system as such.

Many features of parties in contemporary Chile have parallels with the past. Parties in the past were forever dividing or at least had factional infighting barely contained within the parties - and the story in not very different today. Parties in the past changed their ideas in the same way as the contemporary parties of the left and centre have embraced the ideology of neo-liberalism. Parties in the past as much as parties today were controlled and led by elites in a pattern of centralisation characteristic of so much of Chilean politics and not just of parties. In other words it would be premature to assume that we are today witnessing a secular long term decline of the parties that foreshadows their future marginality in the political process.

\section{THE STABILITY OF THE CHILEAN PARTY SYSTEM}

Indeed, the Chilean party system has shown a remarkable degree of stability since the return to democracy in 1990. If we look at the division of opinion between Right, Centre and Left then the proportion of the vote cast for the three different positions in the political spectrum - Right, Left and Centre - has been relatively stable since the 1930s in spite of momentous political, social and economic changes since that date. ${ }^{3}$ But within those blocs there has been considerable volatility intense in some periods as parties divided and sub-divided, and less so at other times as the parties remained more or less intact but saw their share of the bloc vote rise or fall. Montes et. al. (2000: 795) argue that, 'Party penetration in the electorate has not been powerful. Parties have appeared and disappeared with frequency and parties have been relatively weak organisationally'. However, if party blocs or ideological 'families' are examined, the system looks far less volatile. Mair's (1997: 28-9) analysis for Europe applies to Chile. 'The greater part of the increase (in electoral volatility) has in fact been contained within each class-cleavage bloc, and the degree of electoral volatility between the major blocs has actually tended to decline over time... partisan flux has coexisted with a more generalized aggregate electoral persistence'. Table 3 shows the persistence of support for the three major ideological blocs in Chile.

Valenzuela (1999) has made a strong argument for discarding the famous notion of the 'tres tercios', and he is correct to stress that it over-simplifies the position, and ignores the cleavages within each bloc. However in terms of roughly measuring attitudes and political support, dividing voting into the three positions has some - if limited - use. 
TABLE 3: Percentage of vote for parties of the right, centre and left in the Lower House elections $1937-2001$

\begin{tabular}{lcccc}
\hline Year & Right & Centre & Left & Other \\
\hline 1937 & 42.0 & 28.1 & 15.4 & 14.5 \\
1941 & 31.2 & 32.1 & 33.9 & 2.8 \\
1945 & 43.7 & 27.9 & 23.1 & 5.3 \\
1949 & 42.0 & 46.7 & 9.4 & 1.9 \\
1953 & 25.3 & 43.0 & 14.2 & 17.5 \\
1957 & 33.0 & 44.3 & 10.7 & 12.0 \\
1961 & 30.4 & 43.7 & 22.1 & 3.8 \\
1965 & 12.5 & 55.6 & 22.7 & 9.2 \\
1969 & 20.0 & 42.8 & 28.1 & 9.1 \\
1973 & 21.3 & 32.8 & 34.9 & 11.0 \\
$1937-73$ (Mean) & 30.1 & 39.7 & 21.5 & 8.7 \\
1989 & 34.1 & 33.1 & 24.3 & 8.5 \\
1993 & 33.5 & 30.9 & 31.6 & 4.1 \\
1997 & 36.3 & 26.1 & 34.1 & 3.6 \\
2001 & 44.3 & 25.2 & 29.1 & 1.6 \\
\hline
\end{tabular}

Source: Siavelis (1999). 2001 figures from the Ministry of the Interior

Moreover, it is not only at the aggregate level that there is continuity. It is also reflected by the pattern of support at the level of the municipality or commune. Examining voter behaviour at the local level, Valenzuela and Scully (1997: 521) conclude that 'over sixteen years of dictatorship did not change the political profile of the nation's communes'. This is an important finding. It is reinforced by the later data (Valenzuela, 1999: 286) indicating a marked continuity of party strength or weakness in more or less the same congressional constituencies before and after the coup. There is debate about the extent to which the party system has been restructured around a new cleavage - that of for or against Pinochetismo, or in other words pro- or anti-authoritarianism (Torcal and Mainwaring, 2003; Aguero and Tironi, 1999; Valenzuela, 1999). There is undoubtedly some force in this argument (to be discussed later) but it does seem to ignore the deep roots that the parties have created in the social consciousness of a considerable part of the electorate. In other words, reducing the current cleavage to a political one and discarding sociological and cultural ones may well be taking the argument too far. Valenzuela (1999: 275) argues that the current division into two opposing coalitions is the result of a particular political conjuncture and is not a new cleavage in the sense that the religious or class cleavages of the past undoubtedly were. He would explain most voting not as an expression of support for or opposition to authoritarianism but as the 'loyal' vote given to the preferred party or political tendency.

The electoral continuity shown in Table 3 is remarkable in view of the turbulent history of the parties over the past decades - and considering that the electorate almost doubled between the elections 
of 1973 and 1989 , and most voters in 1989 were voting for the first time. A party system that had operated on generally agreed rules of compromise and consensus broke down in the late 1960s and early 1970s as doctrinaire ideologies came to dominate parties of the Left, Centre and Right. Bitter party hostility - in a system described by Sartori (1976: 160) as one of extreme polarisation - led directly to the coup of 1973. After the coup, parties were banned and exiled as a radical military dictatorship imposed a neo-liberal model on the economy and society and effectively changed the map of politics. Hence, in addition to coming to terms with operating clandestinely and in exile, parties, which were used to operating in a state-centred economy performing the role of linking social groups to the state, in future would have to operate in a totally different free-market economy. Finally, even though the parties did manage to regroup during the latter years of the dictatorship, and to overcome the bitter hostility that had divided them in 1973, almost equally momentous events then affected them. For a country in which marxism and anti-marxism were influential ideologies, the collapse of international communism was hugely important. All parties had to come to terms with the market rather than the state, and parties of the Left also had to come to terms with collapse of marxism. Yet the pattern of support for three perceived positions on the political spectrum has remained relatively stable.

Another element of stability has been shown in the pattern of voting for the government and opposition since 1989. The governing Concertación has gained $50 \%$ (or very close to it) in every election since that date, and there have been many. It is true that the fortunes of the individual parties has changed, as indeed occurs in other stable coalition systems, but Table 4 shows a remarkable pattern of overall support for the government. 
TABLE 4: Election results and seat distribution in the Lower House by party and coalition 1989, 1993, 1997, 2001 ( $N=120)$

\begin{tabular}{|c|c|c|c|c|c|c|c|c|c|c|c|c|c|}
\hline & & & 1989(a) & & & 1993 & & & 1997 & & & 2001 & \\
\hline Pact & Party & $\begin{array}{c}\text { Votes } \\
(\%)\end{array}$ & $\begin{array}{c}\text { Seats } \\
\text { (N) }\end{array}$ & $\begin{array}{c}\text { Seats } \\
(\%)\end{array}$ & $\begin{array}{c}\text { Votes } \\
(\%)\end{array}$ & $\begin{array}{c}\text { Seats } \\
\text { (N) }\end{array}$ & $\begin{array}{c}\text { Seats } \\
(\%)\end{array}$ & $\begin{array}{c}\text { Votes } \\
(\%)\end{array}$ & $\begin{array}{c}\text { Seats } \\
\text { (N) }\end{array}$ & $\begin{array}{c}\text { Seats } \\
(\%)\end{array}$ & $\begin{array}{c}\text { Votes } \\
(\%)\end{array}$ & $\begin{array}{l}\text { Seats } \\
\text { (N) }\end{array}$ & $\begin{array}{c}\text { Seats } \\
(\%)\end{array}$ \\
\hline \multirow[t]{5}{*}{ Concertación } & & 51.5 & 72 & 60 & 55.4 & 70 & 58.3 & 49.9 & 70 & 58.3 & 47.9 & 62 & 51.6 \\
\hline & PDC & 26.0 & 39 & 32.5 & 27.1 & 37 & 30.8 & 22.3 & 39 & 32.5 & 18.9 & 23 & 19.1 \\
\hline & PS & (b) & 18 & 15.0 & 12.0 & 15 & 12.5 & 11.1 & 11 & 9.2 & 10.0 & 10 & 8.3 \\
\hline & PPD & 11.5 & 7 & 5.8 & 11.8 & 15 & 12.5 & 12.6 & 16 & 13.3 & 12.7 & 20 & 16.6 \\
\hline & Other & 14.0 & 2 & 6.7 & 4.5 & 3 & 2.5 & 3.9 & 4 & 3.3 & 2.2 & 3 & 1.8 \\
\hline \multirow[t]{4}{*}{ Union Por Chile } & & 34.2 & 48 & 40 & 36.7 & 50 & 41.7 & 36.2 & 47 & 39.2 & 44.8 & 57 & 47.5 \\
\hline & RN & 18.3 & 32 & 26.7 & 16.3 & 29 & 24.2 & 16.8 & 23 & 19.2 & 13.8 & 18 & 15.0 \\
\hline & UDI & 9.8 & 14 & 11.7 & 12.1 & 15 & 12.5 & 14.4 & 17 & 14.2 & 25.2 & 31 & 25.8 \\
\hline & Other & 6.1 & 2 & 1.7 & 8.3 & 6 & 5 & 5.0 & 7 & 5.8 & 5.3 & 8 & 6.6 \\
\hline $\begin{array}{l}\text { Independents \& } \\
\text { others not in major } \\
\text { coalitions }\end{array}$ & & 14.3 & 0 & 0 & 7.8 & 0 & 0 & 13.2 & 3 & 2.5 & 7.77 & 1 & 0.8 \\
\hline
\end{tabular}

Source: Siavelis (1999): for 2001 official figures of the Ministry of the Interior.

a Party identification after the 1989 election was fluid given the limitations on party registration imposed by the Pinochet government, and problems with individual candidate registration. The breakdown of party identification listed here represents the eventual party membership, not the labels candidates used for the election.

bPS candidates ran under the PPD label in 1989 because of party registration problems. Similarly, on the right, most independents later joined a party. The per cent of votes reflects actual results; party composition reflects the eventual outcome.

c This pact was known in previous elections as Democracia y Progreso and Unión por el Progreso

This is shown too in the persistence of a gender gap in voting as shown in Table 5 which does not differ greatly from the gender gap in the pre-1973 period. 
TABLE 5: Percent Votes according to gender

\begin{tabular}{llll}
\hline & & Men & Women \\
\hline 1988 & $\mathrm{Si}$ & 40.31 & 47.5 \\
& No & 59.69 & 52.5 \\
1989 & Buchi & 26.01 & 32.53 \\
& Aylwin & 59.04 & 51.60 \\
1993 & Alessandri & 22.65 & 26.02 \\
& Frei & 58.51 & 57.5 \\
1999 & Lavín & 44.09 & 50.59 \\
& Lagos & 50.86 & 45.36 \\
& Lavín & 45.73 & 51.34 \\
& Lagos & 54.27 & 48.66 \\
\hline
\end{tabular}

Source: La Tercera 13/12/99 and 17/01/2000.

There is also some though lesser stability shown in the level of electoral participation. This has declined and the level of decline is worrying especially for the first time and young voters. Nevertheless, it is important to remember that levels of expectation were extraordinarily high in the first years of the return to democracy and it could be that the levels of participation then recorded were exceptional and that the current levels are more normal and certainly in line with the general trend of lower participation in the modern democracies. It is also important to note that support for anti-system or protest parties or candidates is also very low. One explanation of high levels of participation in elections is the belief that support for the governing Concertación coalition is an affirmation of support for democracy. ${ }^{4}$ On the other hand, voting for the Right, especially for the UDI, was seen by a not insubstantial number of voters as expressing support for the legacy of military rule, (though this was played down in the very skilful political marketing of the UDI in the presidential campaign of 1999/2000). This argument would undoubtedly apply to the early elections following the return to democracy, but one wonders how long it will remain relevant as memories of the Pinochet era fade. 
TABLE 6: Percentage participation rates in elections 1989- 2001

\begin{tabular}{lccccccc}
\hline & 1989 & 1992 & 1993 & 1996 & 1997 & 1999 & 2001 \\
\hline Valid Votes as \% adult population & 81.38 & 70.19 & 73.68 & 61.44 & 53.38 & 68.22 & 62.45 \\
Abstention and Non-Registered & 13.58 & 20.84 & 17.57 & 27.57 & 28.86 & 28.81 & 23.9 \\
Blank and Null Votes & 5.04 & 8.97 & 8.75 & 10.99 & 17.76 & 2.97 & 13.65 \\
Total & 100 & 100 & 100 & 100 & 100 & 100 & 100 \\
\hline
\end{tabular}

Source: Riquelme (1999). For 2001 official figures of the Ministry of the Interior. The elections of 1989 and 1993 are combined presidential and congressional elections; those of 1992 and 1996 are municipal elections; those of 1997 and 2001 are congressional elections only; and 1999 was the first round of the Presidential elections.

\section{EXPLAINING THE STABILITY OF THE CONTEMPORARY CHILEAN PARTY SYSTEM}

Any explanation of the stability of the present party system in Chile has to root that explanation in the central role that parties have played for so long in all three dimensions of party functions discussed earlier. Parties in Chile structured electoral choice; parties recruited leaders, trained elites and, in effect, organised democracy and the political system; and to an extent unusual in Latin America they were the agents of government and of opposition. Chilean parties have shown a remarkable ability to survive all kinds of adverse circumstances - not the least of which was the prohibition on party activities during the Pinochet dictatorship. Valenzuela (1999: 276) refers to what he calls a political landscape (paisaje) with such deep roots in political consciousness that it is capable of surviving a long period of dictatorship and re-emerging with basically the same overall structure (even with new parties) as before.

Before the coup, party strength was measured less in terms of individual membership and more in terms of the number of associations of civil society that were controlled by the parties. The trade union movement, for example, was a veritable battleground for competing allegiances of Communists, Socialists, Radicals and Christian Democrats. But Right-wing parties too colonised similar organisations - from small and medium sized business associations, to associations of lawyers, and other professions. In these circumstances, individual party membership was perhaps less important as an indication of social support than the number of associations under the effective control of the party.

But the parties also attracted loyal and dedicated members. The major reason for individuals to join parties were a combination of ideological conviction and family or community tradition. Each party had its own distinctive ideological position and historical tradition. Powerful sub-cultures of party identification grew up in different regions of the country. Memories and traditions of ideological commitment have created patterns of behaviour - at least of voting - that persist even if the original ideology is much diluted. The fact that most political information seems to be conveyed in family surroundings, rather than through the media, may also help to explain why ideological loyalties have lasted longer than the ideologies themselves. ${ }^{5}$ But if membership of a party was an expression

5 This is the argument of Agüero et al (1998: 174). 'Voters maintain and transmit loyalties far less through parties and other organizations and far more through personal connections'. 
of faith for some, for others it was an essential link in a chain of clientelism. The combination of both factors made the party system particularly strong and inclusive. Such loyalties create a pattern of behaviour - some would call it inertia - which persists over time and resists even the kinds of policy changes that parties in Chile have made in the last decade.

However, there are other institutional or even conjunctural factors that aid party stability. A major problem affecting parties in Latin America is a system of excessive Presidentialism which places the incumbent above, and often in conflict with the parties in congress. By contrast, Chilean Presidents have normally been members of their parties, and in some cases loyal and leading members. There were exceptions such as Ibáñez in 1952 and Jorge Alessandri in 1958, but since then every elected president has had close links with a party. It is true that Presidents do distance themselves from their parties - willingly or unwillingly - but the importance of coalition government ties Presidents to the parties of the coalition. All Presidents since 1990 have based their rule on the parties, and parties are consulted on most issues - not least those of appointment to ministerial and other public sector offices. Admittedly the 1980 Constitution gives great power to the President, but in the politics of consensus that dominated political behaviour since 1990, Presidents work closely with their congress. This could be, as Siavelis (1997: 324) argues, a temporary effect of the needs of the democratic transition. The possibility is that the consensual features of the system will fade and be replaced by conflictual ones, especially if, for example, there is an economic crisis. Yet the consensual approach has been maintained even though there were some difficult crises. The governing alliance even survived primary elections, which chose a Socialist and not a Christian Democrat as presidential candidate for 1999.

The current electoral system - and one forced on the government by the Constitution of 1980 - is also a factor for stability. It creates an enormous incentive to remaining inside one or other of the two major coalitions that have dominated the political landscape since 1990. Even if relations between the individual parties are bad - and at times since 1990 they have been very bad indeed - the consequence of leaving the coalition would be electoral suicide. This is a great constraint on the parties in terms of developing their own separate programmes, and fighting a distinctive electoral campaign. Tironi and Aguero (1999: 157) argue that in effect, the new political division into two coalitions fits the political experience of most Chileans - which is that of support for or opposition to authoritarianism. Hence this new cleavage - as important according to them as the great cleavages of the past - makes the electoral system in some sense appropriate to this new political division.

In sharp contrast to the past (or rather of certain periods of the past) is the absence of ideological competition given the predominance of the ideology of neo-liberalism. Chile is amongst the most neo-liberal countries in the world - not just in the sense of shaping government policy but also as a hegemonic ideology shared by Right, Centre and Left (at least at the elite level - at the popular level it is a different story). Of course there are differences, but they are minor compared with the sharp ideological cleavages of the past. This once more imposes a major constraint on parties - not least on the parties of the Left that moreover, since 1990, have been parties of government and hence further constrained. But a political system in which parties argue over the details of policies rather than the nature of the policies themselves, let alone the legitimacy or not of the current government, is obviously inherently more stable. Yet a note of caution is necessary before one proclaims 'the end of politics'. There is evidence 
of considerable differences over important questions - some of moral issues such as abortion and divorce and other of social justice such as income distribution. It could be, as Valenzuela (1999) argues, that once democracy is properly consolidated in Chile (and there are many constitutional reforms pending) that these issues would once more rise to the forefront of political debate.

Another unusual feature of Chile, and one which gives strength to the party system as a whole, is that the Right is organized and mobilises through parties. The two parties of the Right cover the full spectrum of rightist supporters. Business groups work through normal political channels, and have close ties with the parties of the Right. Although the military did threaten political stability on the issue of human rights, in general it is supportive of the political system, and markedly so after Pinochet retired from active command in 1997. After all, the Constitution is one of military design, and the successful free-market economic model was adopted during military rule. And if there is any reason for the military to make its voice heard, it can do so through the numerous right-wing politicians with links to the military. The Right attracts the votes disproportionately of women, of devout Catholics, and has established a powerful base amongst the poor in the shantytowns of Santiago (Soto, 2001)

What divides parties in Chile? How important is the political memory of dictatorship? How far is support for a party determined by whether the party emerged from the Pinochet government or whether the party was exiled and in opposition to it. This cleavage over the legacy of Pinochet was, undoubtedly, very pronounced in the first years after the return to democracy, and was important in defining government and opposition. Torcal and Mainwaring (2003: 63) go further in their argument and in time, and strongly assert that it is the crucial factor that structures the party system - in contrast, the differences based on class voting or religious belief are modest. Tironi and Aguero (1999: 159) argue that 'the new loyalty to the coalitions seems to be stronger than the old loyalty to the parties.' In effect these authors point to a new political landscape, while Valenzuela (1999) argues for the persistence of the old political landscape. It does not seem possible to resolve this disagreement properly until more time has passed - until the memory of the Pinochet period fades even more, until the governing coalition loses an election and has to cope as opposition, and until democracy is properly consolidated in Chile with a constitution that is the result of democratic accord and not of authoritarian imposition. But the Chilean party system has demonstrated so far a remarkable ability to survive and adapt.

\section{IN WHAT WAYS HAS THE PARTY SYSTEM CHANGED?}

If parties do not change, then they do not last. Chilean parties have shown themselves to be very adaptable to the new circumstances though some more than others. Parties are now much more professional organisations. There are fewer individual members and the meaning of membership has changed as parties have shed much of their ideological fervour and moved to modern methods of campaigning. The mass meetings that characterised the parties in the past have been replaced by the focus-group meeting.

This is partly a consequence of the electoral system. The system favours large coalitions - but it also has the effect of increasing competition between parties inside the same coalition as it forces 
the two candidates for the same list struggle to come first. ${ }^{6}$ Although a series of pacts has diminished the effect of this struggle, especially for the smaller and more important senate, competition between members of the same coalition can be fierce. The system encourages candidate-identification rather than party-identification. Campaigns are fought (and financed) by candidates seeking to establish their individual identity. At election time the level of activity is much greater at the level of the individual candidate headquarters than at the central party offices. Candidates have their own headquarters, their own think-tanks, and their own focus groups. Even the posters that line the main streets at election time are put up by hired help and not by party activists. This candidate-based competition makes sense if the real election in many cases is not between the government and the opposition but inside each coalition list. Party identification remains important to bring out the core or loyal party vote, but successful candidates go beyond that to establish a personal following as well.

Candidates for office do not always identify themselves through their party affiliation but prefer that of the overall coalition - though this is no doubt a political marketing tactic as the party affiliation of most candidates is well known. The Presidential candidate of the Right in 1999 preferred to present himself as a capable technocrat rather than as a politician. That this kind of message was appealing (aided by lavish campaign expenditure and a good record of administration of municipalities where the Right was in control) was shown by the fact that he almost won the Presidential contest in 1999. Closely related to the personalisation of politics is the huge increase in the cost of electoral campaigns. Candidates seek to create a personal following, and for the right candidate with the right policies, businesses are only too willing to fund electoral campaigns -and of influential politicians from all parties.

The parties have also lost much of the organisational support that they received from affiliated associations. Party representatives in Congress no longer can broker favours from the executive. The neo-liberal economic framework limits the scope of government action, and, moreover, the power of congress in the Constitution is sharply reduced, so that it can no longer 'perform its traditional functions of interest representation and satisfaction' (Siavelis, 1997: 37). ${ }^{7}$ On the other hand, some of the major associations that supported the parties are also much weaker. Trade unions, for example, are a shadow of their former influence, and although almost all union leaders are openly members of one or another party, the support they command from the rank and file is both far less numerous and far less committed.

One reason that parties feel less need to recruit members is that most funding comes from private donations. Parties claim that they cover up to $60 \%$ of their expenditures by income from their assets and seek the rest from donations and fees from prominent members (rank and file dues are negligible). There is no state funding of parties in Chile, nor are there any limits on campaign expenditures, nor is there any effective public scrutiny. The only benefit that the parties receive is the right to the allocation of a limited amount of TV and radio time at elections of 30 minutes daily

Except that when it is clear that an alliance is likely to elect only one candidate and when it is also clear that one party or candidate has overwhelming support, the other alliance partner may put up only a token campaign in order to ensure that the votes for the dominant partner are maximised.

As Siavelis (1997: 37) points out this means the end of personalism, clientelism and pork-barrel politics, but by limiting the power of congress it also limits the legitimacy of the party system. 
for presidential and congressional elections. Most funding does not go to the central party but to the individual candidates for elections that are becoming increasingly costly. Even the PS and the PPD are financed largely at the candidate level through business support. Most businesses that make political donations usually do so to a variety of parties as an insurance against an uncertain electoral outcome. The government has tried to pass legislation for the public funding of parties. In 1991 a government project recommended up to US\$ 7 million for the parties; and up to US\$ 17 million for electioneering. But it was defeated in the Senate. A current (2003) initiative with a good chance of success aims to increase transparency and to impose limits on electoral financing, but on the other hand does not propose any system of public financing or other measures to reduce the entrenched power of the existing parties.

How much do elections cost? A parliamentary report in 1994 estimated that in the 1993 congressional elections some candidates spent over US\$ 2 million in the wealthier districts and in the poorer ones US\$ 500,000, and US\$10 million for a presidential campaign. A think-tank report in 1997 gave even higher figures of between US\$4 to US\$ 8 million for senate. Comparatively this is very high - proportionately not far short of Japanese levels and above those of most European countries. ${ }^{8}$ A consequence of this high level of cost is the difficulties it creates for new parties trying to enter the electoral arena. But another consequence is the opportunity this creates for the exercise of influence or even of corruption. Rehren (1997: 327-8) points to a new feature of Chilean politics - 'the penetration of the locality by the market and the introduction of private enterprises as a new component of local political machines and clientelistic networks. It is undeniable that private businesses support local campaigns with contributions almost impossible to control and later do have an important impact in municipal affairs.' This analysis can be extended to other levels in Chilean politics.

In these circumstances, the concept of party militancy loses a great deal of meaning. Individual members have very little influence on party policy, are called upon to perform very few tasks, and unless they have a great deal of money contribute relatively little to the party. Party militancy makes a great deal of sense for those who want a political career or the chance to influence local or national decisions, but apart from the remaining and still strong historical loyalties, Chile seems to be following the pattern of many countries in seeing a decline of mass party membership.

These changes reflect the adjustments that parties have had to make in an era of the dominance of market-based policies. In the political rhetoric of the Right, and indeed amongst some sectors of the government, administration is more important than politics, and there is an emphasis on the need to create consensus and avoid political conflict. Hence important themes are marginal to the political debate. The macroeconomic model is rarely questioned - even though paradoxically the opposition to Pinochet strongly criticised the defects of the economic model. The result is a restricted political agenda with little debate on important issues such as environmental concerns, income inequality, the power and role of the trade unions, ways of increasing political participation. The passionate debate on fundamental issues that the parties encouraged and organised before 1973 has been replaced by a strong desire to limit and control the public agenda. This is understandable given the need for caution and incremental change in order to sustain what was at 
least initially a fragile democracy. But it does not encourage strong voter identification with the parties. The reduction in political patronage and clientelism (though the scale of that reduction has often been exaggerated) available to the parties and to congressional representatives with the switch to the market-based model and the reduction in discretionary allocation of public funds has also not endeared the parties or their representatives to the electorate at large.

Polls show that parties inspire little confidence. However, in the absence of data it is difficult to know if they ever did - and it may be that voters have greater degrees of confidence in their own party than in the parties they oppose. ${ }^{9}$ So the responses have to be treated with caution. An opinion poll in 1998 reported that the institution in which people expressed most confidence was the Catholic Church, with $79 \%$. The Presidency was well regarded with $55 \%$ - but Congress received only $40 \%$ approval; and the parties a mere $24 \% .{ }^{10} \mathrm{~A}$ poll in 2002 reported that only $5 \%$ of those questioned had any degree of confidence in the parties - though such figures are commonplace in Latin America, and indeed even in developed countries. ${ }^{11}$ The number of respondents refusing to express sympathy with either Right, Left or Centre has grown from $32 \%$ in 1990 to $47 \%$ by mid-1997 (Siavelis, 1999). On the other hand, the electorate still classifies the parties very differently on the Left-Right scale. Asked to rank parties on a 1 (Left) to 10 (Right) scale, the UDI was rated on average 8.88; the PDC 5.33; the PPD 3.89 and the PS 2.74. So at least in terms of popular perceptions of party differences the electorate still has a sharp sense of the relevance of the terms Left and Right. ${ }^{22}$

Disenchantment with the parties is directed at what is increasingly seen as a centralised, nonparticipatory party system. There is undoubtedly some truth in these accusations. The way that the parties have dealt - or rather failed to deal - with the demands of women's organisations for greater involvement in party leadership and in decision-taking is a case in point. Women's representation in the Chamber of Deputies rose from only $5.8 \%$ of the total to $8 \%$ in 1994 and $10 \%$ in 1998. In the two Left-wing parties, the PPD and PS, women make up $19 \%$ and $18 \%$ of their congressional representation; but only $5 \%$ of the PDC. On the Right, RN has $16 \%$. The story is similar in the party structures. There is positive discrimination with quotas in the PS and PPD, and women form $33 \%$ of the Political Commission of the PS and $27 \%$ of the PPD, (but only $17 \%$ of the PDC). The danger is that quotas become ceilings, and at the existing level is insufficient to develop a critical mass inside the parties (Waylen, 2000: 820).

\section{CONCLUSIONS: PARTIES AND DEMOCRACY IN CHILE}

The major political issue in Chile in 1990 was how well democracy could survive the multiple tests to which it was subjected with the ending of authoritarian government. Many institutions of the past survived into the democratic period - not least the Constitution and an electoral system, which the democratic coalition rejected. One of the primary functions of the parties was to contribute to the consolidation of democracy. As time passed, attention focused less on the question of the survival

I am grateful to Roberto Espíndola for this point.

Data from the Latinobarómetro Report for 1998, reported in El Mercurio, 16 June 1999.

National Survey, CERC, May 2002. Figures from their website, www.cerc.cl

From the CERC survey of July 1999. 
of democracy, for that now looked secure, and more on the quality of democracy. So if the first question is how far the parties contributed to a successful transition, the second is more concerned with the contribution of the parties to the quality of democracy.

However, a problem in answering these questions is that in important aspects the political system in Chile is an artificial one, more the product of the authoritarian regime rather than the design of democratic policy-makers. Hence parties do not operate in an institutional framework of their own choosing but in one imposed on them by an (anti-party) military regime. Governments since 1990 have tried to abolish the designated senators, change the electoral system, secure greater control over the military, increase the powers of congress - but all have failed in the face of an in-built majority for the Right in congress. The only major democratising constitutional reform passed was the democratic election of municipal councillors (though in practice many of the military prerogatives contained in the Constitution have diminished in practice) (Angell, 2003).

Parties have had to shape their behaviour to an institutional framework outside their control. The question then is how far behaviour imposed from outside has created a pattern which might survive even if the external framework, the electoral system for example, were to change? Carey (1998) asks the question - 'are the two major coalitions merely marriages of convenience made necessary by the method of aggregating votes imposed by the outgoing dictatorship, but otherwise not important in structuring legislative behaviour?' His answer is that there is good reason for thinking that they are more than a mere marriage of convenience - apart from the sheer longevity of the coalitions, his research finds that the institutions that direct the Chamber of Deputies are organised on a coalition basis, and that more importantly coalition membership is a better predictor of legislative voting than party membership. Tironi and Aguero (1999: 162) argue that not only has the bipolar coalition system proved to be very durable but that has also successfully incorporated the political divisions of the past, notably that over religion.

These are convincing arguments but they also rest to some extent on assumptions about future developments. If the reform of the constitution is successful, if the Right does take power, if the Christian Democrats continue to decline, then would the present pattern of political behaviour persist - or would there be a reversal to a more central role for individual parties rather than the coalitions? The question is impossible to answer but it is not an implausible scenario.

If we shift the analysis to look at parties as agencies of government, and of opposition, then relatively it seems clear that parties have played a positive role in strengthening governance in Chile. The coalition formed to contest the plebiscite in 1988 and the elections of 1989 was an instrumental one, forced by sheer electoral necessity to collaborate, and united by opposition to authoritarianism. But this pact has lasted for well over ten years, has successfully fought and gained over $50 \%$ (or very close) of the vote in a plebiscite, three presidential, four congressional and three municipal elections, has witnessed an unprecedented successful period of economic growth and dealt with complex political issues such as justice for human rights abuses

Can we argue then that Chilean parties have made the transition from mass parties of ideology to modern parties of effective government? The transition is not an easy one to make, and arguably the parties in Chile have made it more successfully than in a number of other Latin American countries. Indeed, the political and economic success of the transitional governments owes a great deal to the role and function of the parties. Democracy in Chile in a way not typical of Latin 
America is party democracy. Mair's (1997: 153) analysis of the changing role of parties in Western Europe may be applied to Chile:

On the ground, and in terms of their representative role, parties appear to be less relevant and to be losing some of their key functions. In public office, on the other hand, and in terms of their linkage to the state, they appear to be more privileged than ever. In terms of the classic functions of party, then it might be concluded that while some of these functions have been undermined (such as the articulation of interests and the aggregation of demands, and perhaps also the formulation of public policy) other functions have acquired an increased importance and visibility (such as the recruitment of political leaders and, above all, the organization of government).

Parties played a key role in the politics and economics of the transition, and in a process of economic development without parallel in recent Chilean history. Parties have contributed to managing some of the thorny issues of the transition - not least that of the human rights issue. Parties have contributed to the institutionalisation of a generally well-functioning political system. But the challenges have changed and it is less clear that the party system is capable of dealing with those challenges. The fact that there is a general trend to be critical of parties is of little comfort to politicians in any particular country. In Chile as the memory of authoritarianism becomes weaker and as the establishment of democracy becomes firmer, then the parties have to face different challenges. There are demands for the parties to become more participatory, more inclusive, to accept the positive role of political conflict as well as that of political consensus, and to emphasise their differences with other parties rather than their agreement, not simply with parties of the opposite coalition but within the coalition as well. How well they respond to these demands will be important in the future for the quality of democracy in Chile.

\section{REFERENCES}

Agüero, Felipe, Eugenio Tironi, Eduardo Valenzuela and Guillermo Sunkel. 1998. "Votantes, Partidos e Información Política: La Frágil Intermediación Política en el Chile Post-Autoritario". Revista de Ciencia Política, XIX (2): 159-193.

Alcántara, Manuel and Roberto Espíndola (eds). Forthcoming 2004. Political Parties in Latin America, London: Routledge Press.

Allamand, Andrés. 1999. La Travesía del Desierto. Santiago: Aguilar.

Angell, Alan. 2003. "The Pinochet Factor in Chilean Politics". In The Pinochet Case, edited by Madeleine Davis London: Institute of Latin American Politics.

Angell, Alan, Pamela Lowden and Rosemary Thorp. 2001. Decentralizing Development: The Political Economy of Institutional Change in Colombia and Chile. Oxford: Oxford University Press.

Cañas, Enrique. 1998. "Los Partidos Políticos". In Chile en los Noventa, edited by Cristián Tolosa and Eugenio Lahera Santiago: Presidencia de la República, Dolmen Ediciones.

Carey, John. 1998. "Parties, Coalitions and the Chilean Congress in the 1990s", paper presented at Latin American Studies Association Conference.

Dalton, Rusell and Martin Wattenberg, (eds). 2002. Parties without Partisans: Political Change in Advanced Industrial Democracies. Oxford: Oxford University Press

Garretón, Manuel Antonio. Forthcoming 2004. "Exploring Opacity: The Financing of Politics in Chile". In Money, Elections and Party Politics: Experiences from Europe and Latin America, edited by. Carlos Malamud and Eduardo Posada-Carbó London: Institute of Latin American Studies. 
Gunther, Richard, José Ramón Montero and Juan Linz (eds). 2002. Political Parties: Old Concepts and New Challenges. Oxford: Oxford University Press.

Huneeus, Carlos. 1998. "Chile's New Democracy: Political Funding and Economic Transformation". In Financing Democratization, edited by Peter Burnell and Alan Ware Manchester: Manchester University Press.

Huneeus, Carlos. 2000. El Régimen de Pinochet. Chile: Editorial Sudamericana.

Huneeus, Carlos. 2002 "A Highly Institutionalized Political Party: Christian Democracy in Chile", unpublished paper.

Huneeus, Carlos and Luis Maldonado. 2002. "Demócratas y nostálgicos del antiguo régimen”. Buenos Aires: paper CLACSO. Mair, Peter. 1997. Party System Change. Oxford: Oxford University Press.

Montes, J. Esteban, Eugenio Ortega and Scott Mainwaring. 2000. "Rethinking the Chilean Party System". Journal of Latin American Studies 32 (3): 795-824.

Pharr, Susan and Robert Putnam (eds). 2000. Disaffected Democracies: What"s Troubling the Trilateral Countries. Princeton: Princeton University Press.

Rehren, Alfredo. 1997. "Corruption and Local Politics in Chile". Crime, Law and Social Change 25: 323-334.

Riquelme, Alfredo. 1999. “QQuiénes y por qué ‘no están ni ahí? Marginación y/o automarginación en la democracia transicional. Chile. 1988-1997". In El Modelo Chileno: Democracia y Desarrollo en los Noventa, edited dy Paul Drake and Iván Jaksic. Santiago: LOM Ediciones.'

Sánchez, Fernando. 2003. Dealignment in Costa Rica: a Case Study of Electoral Change. D Phil thesis (submitted) University of Oxford.

Sartori, Giovanni. 1976. Parties and Party Systems: A Framework for Analysis. Cambridge: Cambridge University Press.

Scully, Timothy. 1992. Rethinking the Center: Party Politics in Nineteenth and Twentieth Century Chile. Stanford CA: Stanford University Press.

Siavelis, Peter. 1997. "Executive-Legislative Relations in Post-Pinochet Chile: A Preliminary Assessment". In Presidentialism and Democracy in Latin America, edited by Scott Mainwaring and Matthew Shugart. Cambridge: Cambridge University Press.

Siavelis, Peter. 1999. “Continuidad y Transformación del Sistema de Partidos en una Transición 'Modelo'." In El Modelo Chileno: Democracia y Desarrollo en los Noventa, edited by Paul Drake and Ivan Jaksic. Santiago: LOM Ediciones.

Soto, Angel. 2001. Historia Reciente de la Derecha Chilena: Antipartidismo e Independientes 1958-1993. Doctoral thesis, Universidad Complutense de Madrid.

Tironi, Eugenio and Felipe Agüero. 1999. "Sobrevivirá el Nuevo Paisaje Chileno?". Estudios Públicos 74: 151-168.

Torcal, Mariano and Scott Mainwaring. 2003. "The Political Recrafting of the Social Bases of Party Competition: Chile, 197395". British Journal of Political Science 33 (1): 55-84.

Valenzuela, J Samuel. 1999. "Reflexiones sobre el Presente y Futuro del Paisaje Chileno a la Luz del Pasado". Estudios Públicos 75: 273-290

Valenzuela, J Samuel. 1995. “Orígenes y Transformaciones del Sistema de Partidos en Chile”. Estudios Públicos 58: 5-77.

Valenzuela, J. Samuel and Timothy R. Scully. 1997. "Electoral Choices and the Party System in Chile: Continuities and Changes at the Recovery of Democracy". Comparative Politics 29 (4): 511-27.

Waylen, Georgina. 2000. "Gender and Democratic Consolidation: A Comparison of Argentina and Chile". Journal of Latin American Studies 32 (3): 765-93.

World Bank. 2002. Global Governance Project. Washington DC: World Bank.

Alan Angell es profesor de Política Latinoamericana. Es integrante del St. Antony's College y Director del Centro Latinoamericano de la misma institución. Su área de estudio es la política de Chile, la política de la izquierda en América Latina, políticas sociales y la relación entre legislación y política. Entre sus publicaciones destacan Politics and the Labour Movement in Chile (1972); y En Busca de la Utopia: La Politica Chilena entre Alessandri y Pinochet (1994); editado con el Dr. Benny Pollack, The Legacy of Dictatorship: Political, Economic and Social Change in Pinochet's Chile (1993). Su más reciente investigación fue en conjunto con Rosemary Thorp and Pamela Lowden y fue editada como Decentralising Development: the Political Economy of Institutional Change in Colombia and Chile (OUP 2001).

(E-Mail: alan.angell@latin-american-centre.oxford.ac.uk) 